\title{
H.G. Stoker (1999-1993) as Christelike filosoof: 'n Historiese legende en ikoon, of nog steeds 'n kontemporêre mentor?
}

Author:

Barend J. van der Walt ${ }^{1}$

Affiliation:

${ }^{1}$ School for Philosophy, North-West University,

Potchefstroom Campus,

South Africa

Correspondence to:

Bennie van der Walt

Email:

benniejvanderwalt@gmail. com

Postal address:

7 Bezuidenhout Street,

Oewersig, Potchefstroom

2531, South Africa

Dates:

Received: 24 Nov. 2011

Accepted: 23 Apr. 2012

Published: 19 Mar. 2013

How to cite this article: Van der Walt, B.J., 2013, 'H.G. Stoker (1999-1993) as Christelike filosoof: 'n Historiese legende en ikoon, of nog steeds ' $n$ kontemporêre mentor?', In Die Skriflig/In Luce Verbi 47(1), Art. \#86, 15 pages. http://dx.doi.org/10.4102/ ids.v47i1.86

\section{Copyright:}

(C) 2013. The Authors. Licensee: AOSIS

OpenJournals. This work is licensed under the Creative Commons Attribution License.

Read online: 'n Tradisie, wat 'n filosofiese tradisie insluit, kan alleen lewend bly as die verhaal daarvan aan die jonger geslag oorvertel word. Daarom bied hierdie inleidende en oorsigtelike artikel aan die leser iets oor die unieke filosofie van die Suid-Afrikaanse denker, Henk Stoker. Ter inleiding behandel dit die moontlike redes waarom sy denke in Suid-Afrika en elders vandag relatief onbekend is en minder invloedryk was in vergelyking met dié van die twee ander vaders van 'n reformatoriese filosofie, naamlik Dirk H.Th. Vollenhoven en veral Herman Dooyeweerd. Daarna word aandag geskenk aan die Suid-Afrikaanse milieu waarbinne sy filosofie gebore is. Die moontlike interne en eksterne teologiese en filosofiese invloede van veral Herman Bavinck (1854-1921) en Max Scheler (1874-1928) word behandel. Vervolgens word op enkele van Stoker se oorspronklikste bydraes tot die Christelik-filosofiese tradisie gewys. 'n Vlugtige blik word op die wedersydse kritiek tussen Stoker, Dooyeweerd en sekere leerlinge van Dooyeweerd gewerp. Ten slotte kan daar, in die lig van hierdie onderlinge verskille, sekere wanopvattings reggestel word, byvoorbeeld dat 'n Reformatoriese filosofie 'n statiese en geslote sisteem is.

H.G. Stoker (1899-1993) as Christian philosopher: historical legend and icon, or still a contemporary mentor? Tradition which includes a philosophical tradition, can only been kept alive when its story is told to younger generations. This is the motivation behind this introductory overview of the unique philosophy of the South African philosopher, Henk Stoker. In comparison with the two other founders of a reformational philosophy, Dirk H.Th. Vollenhoven (1892-1978) and especially Herman Dooyeweerd (1994-1977), Stoker's ideas are in South Africa, as well as abroad, less well-known among reformed people. The introductory part of this article, therefore, investigates the possible reasons for the relatively small impact of his thinking. The next section requires attention for the South African context in which his Christian philosophy was born. This is followed by a detailed discussion of the possible internal and external theological and philosophical influences of especially Herman Bavinck (1865-1921) and Max Scheler (1874-1928) on the emergence of Stoker's philosophy of the idea of creation. A few of Stoker's original contributions to a Christian philosophy are then highlighted. Next the debate between Stoker and Dooyeweerd and some of Dooyeweerd's followers is reviewed. Finally, in the light of these differences between two of the fathers of the triumvirate already at the origin of a Reformational philosophy, the misconception that this kind of philosophy is a static and closed system, should be corrected.

\section{Inleiding: Aansluiting, oogmerk, aanpak en opset}

Ter inleiding moet die volgende in gedagte gehou word:

\section{Aansluiting}

Hierdie bydrae vorm die tweede deel van 'n trilogie oor die grondleggers van 'n Christelike filosofie: D.H.Th. Vollenhoven (1892-1978), H. Dooyeweerd (1894-1977) in Nederland en H.G. Stoker (1899-1993) in Suid-Afrika. In die eerste artikel van die trilogie word Dirk Vollenhoven se denke aan die lesers bekend gestel. In hierdie bydrae verskuif die fokus na die Suid-Afrikaner, Henk Stoker se wysbegeerte. Die derde artikel in die reeks handel oorsigtelik oor die bydrae van Herman Dooyeweerd.

Al drie hierdie denkers was daarvan oortuig dat 'n Christelike benadering tot die filosofie moontlik en nodig is. Verder het hulle ook saamgestem dat 'n Christelike filosofie ook belangrik is vir 'n Christelike oriëntasie in ander wetenskappe. So 'n filosofie moet byvoorbeeld nie alleen 
bedag wees op die resultate van ander wetenskappe nie (die reformatoriese teologie ingesluit), maar dit bied ook 'n belangrike en noodsaaklike insig op al hierdie dissiplines. Vandaar die regverdiging van hierdie drie bydraes in ' $n$ tydskrif wat primêr teologies gerig is.

\section{Oogmerk}

Ter inleiding tot die eerste artikel (oor Vollenhoven) is die vraag gestel wat ' $n$ tradisie, 'n filosofiese tradisie ingesluit, behels en hoe dit lewend gehou kan word. Dit vorm ook die agtergrond van die huidige bydrae oor Stoker (vgl. die subtitel). In die vorige bydrae is aangetoon dat, om lewend te bly, elke tradisie onder andere 'n verhaal nodig het wat ook aan latere geslagte oorgedra moet word. So 'n verhaal bevat gewoonlik ook die geskiedenis van belangrike figure (bv. politieke helde of invloedryke denkers) wat as inspirasie vir die huidige geslag binne ' $n$ tradisie moet dien.

In die eerste artikel ontbreek die waarskuwing egter dat sulke leidende figure uit die verlede op verkeerde maniere beskou kan word nie. Volksages kan 'n legendariese volksheld tot so ' $n$ mate romantiseer en vereer dat dit glad nie meer met die historiese werklikheid klop nie. Die geïdealiseerde beeld is dikwels ook te veel aan die verlede gebonde, sodat hy of sy weinig betekenis meer vir die hede het. 'n Ikoon het ook weinig waarde vir vandag, omdat hy of sy onbereikbaar hoog bo die gewone mens verhef word.

In hierdie bydrae wil ek Stoker dus nóg as 'n historiese legende van die destydse Potchefstroomse Universiteit van Christelike Hoër Onderwys (Puk) ${ }^{1}$ (vgl. Van der Schyff 2005), nóg as 'n ikoon van 'n Christelike filosofie op Suid-Afrikaanse bodem beskou. Stoker self sou beswaar gehad het indien sy nageslag hom as onfeilbaar sou verklaar. Ek wil hom eerder tipeer as 'n mentor, dit wil sê 'n raadgewer, gids of leidsman op die pad van reformatoriese denke (vgl. Van der Merwe 1994).

\section{Aanpak}

Die vraag kan natuurlik deur lesers gestel word hoe Stoker vandag (hy is reeds twintig jaar gelede in 1993 oorlede) nog 'n mentor kan wees. Die meeste van sy eerste studente is reeds oorlede of in hulle tagtigerjare. My antwoord op hierdie vraag haal ek uit die preek van dr. C.J. Malan by Stoker se begrafnis (op 19 Mei 1993) op Potchefstroom. Sy teks was 2 Konings 13:20-21. Dit het kortliks die volgende ingehou:

Elisa, 'n groot profeet en leier van die volk het soos alle vlees ook gesterwe. Die volk was bedroef oor hulle leermeester se heengaan. Wie sou hulle nou verder lei? Omdat dit vir hulle lyk asof alles verlore is, laat die Here 'n wonderwerk gebeur. Toe mense op 'n dag by die begraafplek aankom om 'n dierbare van hulle te begrawe, sien hulle 'n Moabitiese bende in aantog. Tyd vir 'n behoorlike begrafnis was daar nie. Paniekbevange het die begrafnisgangers die naaste graf Christelike Hoër Onderwys PU vir CHO was, word daar in die artikel deurgaans informeel na verwys as Puk. oopgemaak - toevallig dié van Elisa - en die lyk in die graf gegooi. Toe die dooie in die profeet se graf val, het hy weer lewendig geword.

Waarom so 'n wonder? Elisa het tydens sy lewe in die krag van die Here ook dooies lewendig gemaak. Noudat hy dood is, moet die Israeliete egter nie dink dat hy niks meer beteken nie. God kan die werk van 'n mens laat voortgaan al is hy of sy reeds dood. Meer nog: God se werk in hierdie wêreld gaan voort ondanks die mens se aan- of afwesigheid.

Malan het hierdie Skrifgedeelte ook toegepas op die lewe en werk van Stoker. Hy was 'n voorbeeld van geloof wat bly leef in die harte van sy dierbares en talle studente, sowel as deur sy baie geskrifte.

Hierdie artikel sluit aan by die laaste gedagte. Deur sy geskrewe nalatenskap kan Stoker nog steeds 'n mentor vir vandag wees. Iemand se geskrifte kan egter selfs in die vergetelheid raak. Stoker is vandag nie meer so 'n bekende naam soos 40 jaar gelede nie en daarom moet ' $n$ jonger generasie weer opnuut daarop bedag gemaak word.

Hierdie bydrae is dus nie daarop gerig om Stoker se filosofie as geheel of as 'n onderdeel daarvan indringend te bespreek nie. Dit is oorsigtelik van aard, wil 'n algemene weergawe bied en met behulp van bibliografiese verwysings die huidige lesers uitnooi om self Stoker se werke opnuut te lees, te bestudeer en daardeur geïnspireer word.

Die outeur het by die aanpak van hierdie artikel voor die keuse gestaan om óf deeglikheid en noukeurigheid aan verstaanbaarheid op te offer óf ingewikkelde filosofiese kos aan sy lesers te bied - wat heel moontlik nie filosowe is of niks van Stoker se filosofie weet nie. My keuse het, weens die ingewikkeldheid van die materiaal ter sprake, op eersgenoemde geval, naamlik verstaanbaarheid. Hierdie is dus 'n, soms dalk té, vereenvoudigde weergawe. (Gepopulariseerde wetenskaplikheid is in alle geval 'n beter opsie as onwetenskaplike populariteit.) Ter wille van oorsigtelikheid word die ses hoofafdelings gegee waarvolgens hierdie oorsig sal verloop:

\section{Opset}

Ter inleiding sal die vraag gestel word waarom Stoker se filosofie (in vergelyking met dié van byvoorbeeld Dooyeweerd) relatief onbekend en sy denke minder invloedryk was. Dit word in die tweede plek gevolg met iets oor sy lewensloop. Derdens word die moontlike invloede by die ontstaan van sy filosofie breër behandel. Verder word die aandag op enkele van sy besondere bydraes gevestig. Vervolgens word daarop gewys dat Stoker en Dooyeweerd by die ontstaan van 'n Christelike filosofie nie bloot dieselfde deuntjie getokkel het nie, maar soms grondig van mekaar verskil het en mekaar onderling gekritiseer het. Dit maak dit moontlik om hierdie verkenning af te sluit deur te wys op die ongegrondheid van sekere wanvoorstellings in verband met 'n Christelike filosofie. 


\section{Moontlike redes vir die relatiewe onbekendheid en beperkte invloed van Stoker se filosofie}

Hierbo is reeds genoem dat hierdie nuwe bekendstelling van Stoker nodig is, omdat sy naam en werk nie meer op breë bekendheid aanspraak kan maak soos 40 of 50 jaar gelede nie. Behalwe die probleem van 'n tydsgaping is daar egter meer faktore wat ' $n$ rol kon gespeel het. Vooraf net die opmerking dat verskeie van die redes wat Zylstra (1975:29-32) noem vir die beperkte invloed van ' $n$ Christelike benadering tot die filosofie in die algemeen, ook op Stoker van toepassing is. Hierdie redes word egter nie hier herhaal nie.

\section{'n Internasionale vergelyking}

As ' $n$ mens in gedagte hou hoe belangrik die vertel van die verhaal van 'n tradisie in die oordra daarvan is, word 'n belangrike rede vir die relatiewe onbekendheid van Stoker ook duidelik. Terwyl daar oor die lewe en werk van Dooyeweerd (vgl. Verburgh 1989) en Vollenhoven (vgl. Stellingwerff 1992) alreeds biografieë bestaan, besit ons, behalwe vir die kort opstel van Raath (1994a), nog nie een oor Stoker nie. (Dalk 'n belangrike taak vir sy seun, prof. P.H. Stoker en/of kleinseun, prof. H.G. Stoker Jnr?)

Soek 'n mens na die nodige erkenning van die rol van Stoker in die breëre beweging van ' $n$ Christelike filosofie, word jy ook teleurgestel. Die weergawe van Van Dijk en Stellingwerff (1961) is baie kort en dek bowendien net die tydperk van 1935-1960. Die oorsig van Klapwijk (1980) is waardevol, maar beperk tot filosofie aan die Vrije Universiteit tussen 1880 en 1980. Die poging van Stellingwerff (2006) is weens verskillende ander redes onbevredigend. Die teleurstellende is egter dat die Suid-Afrikaanse deel van die geskiedenis nie in enige van hierdie drie bronne behandel word nie. Stoker se denke word waarskynlik slegs as 'n 'uitvoerproduk' uit Nederland beskou en nie as belangrik genoeg om die nodige aandag te ontvang nie.

\section{In Suid-Afrika}

Terwyl daar oor Dooyeweerd se denke al ongeveer 15 proefskrifte verskyn het, besit ons slegs die minder geslaagde poging van Malan (1968) oor Stoker. Na 'n festschrift (vgl. Bingle \& Du Plessis 1971), waaraan ook internasionale skrywers deelgeneem het, verskyn daar weinig meer oor Stoker, behalwe vir 'n 1994 huldigingsuitgawe 59(3\&4) van die tydskrif Koers wat na sy oorlye uitgegee is, en (sover my kennis strek) slegs twee verhandelings oor sy filosofie: die een deur sy kleinseun (vgl. Stoker Jnr 1983) en die ander deur Van der Walt (2009).

Onbekendheid lei ook tot 'n beperkter invloed. Van der Walt (2009:82-87) voer enkele redes aan vir Stoker se beperkte invloed, plaaslik en oorsee.

\section{Vier moontlike oorsake by Stoker self}

Wanneer die kwaliteit van sy werk in ag geneem word, het Stoker minder invloed gehad as wat verwag kon word. Die feit dat Stoker hoofsaaklik in sy moedertaal (Afrikaans) geskryf het, kon wel 'n oorsaak wees, hoewel nie die enigste en hoofrede nie (Van der Walt 2009:83). Enkele van sy belangrikste geskrifte wat wel in Engels beskikbaar is, is Stoker 1967a, 1967b, 1967c, 1971, 1976 en 2010. Na 2007 (vgl. Stoker 2007, 2008) is Stoker se publikasies ook elektronies beskikbaar. (Behalwe die reeds genoemde groter publikasies in Engels, verskyn daar op die Stoker-CD ook heelwat Engelse artikels in agt verskillende plaaslike en oorsese tydskrifte.)

Stoker se soms omslagtige styl (sy studente het hom 'die wysgeer-tussen-hakies' genoem) kon ook 'n rol gespeel het. Die meeste wysgere se taalgebruik is egter nie maklik verstaanbaar nie!

As 'n derde moontlike rede noem Van der Walt (2009:84) Stoker se visie op die teologie, naamlik dat dit die ander wetenskaplikes se toegang tot die Skrif beperk. Teoloë het nie beswaar gehad dat die teologie vir Stoker die toegangspoort tot die Skrif was nie, maar Christelike filosowe het nie daarvan gehou nie en dit as 'n skolastieke res by Stoker beskou (sien ook later Stoker se 'Tweefaktor ontologie se implikasies').

'n Laaste moontlike rede vir die geringe impak wat Stoker se denke gehad het (vgl. Van der Walt 2009:86), was die feit dat hy apartheid goedgepraat het (vgl. Stoker 1967a; Van Wyk 2001), terwyl dit sowel in Suid-Afrika as in die buiteland al duideliker begin word het dat dit nie in die lig van die Skrif geregverdig kan word nie.

\section{Omstandighede wat nie verband hou met Stoker se denke nie}

'n Mens moet egter versigtig wees om die feit dat Stoker se denke vandag minder bekend is uitsluitlik aan swakhede of gebreke in sy filosofie toe te skryf. Dit moet byvoorbeeld in gedagte gehou word dat die akademiese wêreld in SuidAfrika ook deur ons politieke isolasie oor baie jare geraak is. Dit kon moontlik internasionale belangstelling in Stoker beïnvloed het.

Verder moet ook latere institusionele ontwikkelinge by die universiteit waaraan Stoker vir 40 jaar verbonde was in berekening gebring word. Ongelukkig moet gekonstateer word dat die Puk bestuur (veral sedert ongeveer 1990) nie die vak en die departement Filosofie vertroetel het nie. (Die verpligte kursus in filosofie vir voornemende teologiese studente is ook geskrap.) Verder het die Puk reeds voor sy samesmelting en naamsverandering tot die Noordwes-Universiteit - ook vinnig gesekulariseerd geraak (vgl. Van Eeden 2006), sodat 'n Christelike filosofie en wetenskapsbeoefening (Stoker se ideaal) al minder belangrik geword het. Bowendien is filosofie ook nie 'n 'brood-enbotter' vak nie.

\section{Persoonlike redes}

Afgesien van die voorafgaande moet ook die volgende faktore buite Stoker om onthou word, naamlik dat alle mense nie noodwendig in filosofie belangstel nie. Die feit dat 
vakspesialisasie daartoe lei dat mense al minder buite hulle eie vakgebied lees, is ' $n$ volgende faktor. Derdens veroorsaak beroepsdruk dat die tyd vir wyer belangstelling as wat daagliks vereis word beperk is.

Ten slotte moet egter onthou word dat 'n beperkte invloed nie geen invloed beteken nie en ook nie hoef te beteken dat die invloed nie diepgaande was nie (vgl. Raath 1994b oor Stoker se akademiese nalatenskap; vgl. ook Heyns 1994 vir die belang van Stoker se filosofie spesifiek vir die teologie).

\section{Enkele flitse uit Stoker se lewensgeskiedenis}

Oor Stoker as mens kan 'n mens vandag heelwat aflei uit die verskillende in memoriae wat na sy dood verskyn het (vgl. byvoorbeeld Duvenage 1993; Raath 1994a; Van der Merwe 1993; Van der Walt 1993). Die fokus val hier egter nie op die persoon nie, maar eerder op die milieu waarbinne hy moes lewe en werk.

\section{Onrustige tye}

Uit die kort curriculum vitae (van slegs twee en 'n halwe bladsy) in die Stoker-festschrift (vgl. Bingle \& Du Plessis 1971:7-9), sou 'n mens maklik kon aflei dat Stoker 'n heel gemaklike en rustige lewe gehad het - vandaar sy indrukwekkende lys van publikasies plus talle M- en D-studente (vgl. Bingle \& Du Plessis 1971:303-322; Stoker 1970:435-442). Dus glad nie sulke onrustige, onseker tye soos dié waarin ons huidige jonger generasie moet oorleef nie. Die geboorte van die Christelike filosofie was nie 'n moeilike bevalling nie!

Om hierdie rede word hier nie 'n volledige lewensbeskrywing gegee nie, maar word die klem slegs op die teendeel gelê: Stoker het in veelbewoë, spanningsvolle tye geleef met groot verdeeldheid selfs onder sy eie volksgenote. Nogtans het hy hom nie daardeur van stryk laat bring nie, maar vir 'n ideaal geleef. Op hierdie wyse kon hy, ten spyte van 'n groot mate van isolasie aan die verre Suidpunt van Afrika, 'n medegrondlegger van die Christelike filosofie word.

Hier volg slegs enkele flitse uit politiek-sosiale omstandighede en botsende ideologieë waarbinne hy gebore, opgegroei en gewerk het en 'n pad vir reformatoriese filosofie moes oopkap.

\section{Die Anglo-Boereoorlog en Eerste Wêreldoorlog (WOI)}

Stoker was nog 'n baba tydens die vernietigende Engelse oorlog teen Suid-Afrika (1899-1902), maar in sy jeug het hy definitief die nagevolge daarvan ervaar. Ook die Eerste Wêreldoorlog het Suid-Afrika nie onaangeraak gelaat nie. Stoker was egter vasbeslote om daarna sy studies oorsee voort te sit.

\section{Hoe Stoker uiteindelik in Duitsland promoveer}

Die Vrije Universiteit in Amsterdam, Nederland was destyds die aangewese plek waar Calviniste uit Suid-Afrika gewoonlik hulle studies voortgesit het (vgl. Schutte 2005:668-739 se lang lys van Suid-Afrikaners wat vanaf 1881 tot 2004 aan die VU studeer het). Hoe dit egter gebeur het dat Stoker uiteindelik nie aan die VU nie, maar onder Max Scheler (1874-1928) in Keulen gepromoveer het (vgl. Stoker 1925), is 'n interessante verhaal (vgl. Bril in Vollenhoven 1982:101).

President Paul Kruger het tydens sy ballingskap in Europa kontak met ds. S.O. Los gehad, wat hom later na Switserland vergesel het. Uit erkentlikheid kry Los, na Kruger se dood, 'n hoogleraarskap in Suid-Afrika (Potchefstroom). Hy keer egter later terug na sy moederland. Stoker wou aanvanklik onder H. Bavinck (1854-1921) promoveer - Kuyper (1837-1920) was reeds oorlede - maar hy is ook intussen oorlede. Toe Stoker op 23-jarige leeftyd in 1922 in Den Haag aankom, soek hy dus eers advies by Los oor verdere studiemoontlikhede. Los verwys hom na dr. Vollenhoven, wat toe nog predikant in Den Haag was. Vollenhoven het egter na sy eie promosie in 1918, op advies van Buytendijk, in 1920 'n studieprogram by F. Krüger in Leipzig (Duitsland) voltooi. Ook op advies van Buytendijk, besluit Stoker om onder Scheler in Duitsland te gaan promoveer. Buytendijk staan ook, soos Scheler, as 'n fenomenoloog bekend (vgl. byvoorbeeld Buytendijk 1951 vir interessante korrespondensie tussen Stoker en Buytendijk; vgl. ook Beijk \& Van der Merwe 1994)

Scheler was destyds een van die toonaangewende filosowe in Duitsland en selfs in Europa. Na sy vroeë dood in 1928, besing onder andere Heidegger en Ortega Y. Gasset hom as '... the strongest philosophical force in Germany, nay, in contemporary Europe and in contemporary philosophy as such'. In 1954 skryf die vorige pous (Johannes Paulus II), destyds nog dr. Karol Wojtyla, sy proefskrif oor Scheler se etiek.

Stoker (1941a:4-5) vertel iets oor die haglike omstandighede waarin die Duitse volk na die Eerste Wêreld Oorlog (WOI) geleef het wat hulle 'n maklike prooi van die NasionaalSosialisme gemaak het. Dit het weer tot die Tweede Wêreldoorlog (WOII) gelei. Toe was Stoker reeds lank terug in Suid-Afrika, getroud, vader van drie kinders en verbonde aan die Puk. WOII het egter ook nie Suid-Afrika onaangeraak gelaat nie.

\section{'n Gevange kommandant van die Ossewa Brandwag}

Ruimte laat dit nie toe om in hierdie artikel op die stormagtige politieke situasie in Suid-Afrika en ook aan die Puk gedurende die dertigerjare, WOII en die 'storm en drang' van die veertigerjare in te gaan nie (vgl. Van der Schyff 2003:476-527). Dit is genoeg om te vermeld dat baie Suid-Afrikaners teen die Britse imperialisme in Suid-Afrika was en ook teen Engeland se oproep van sy koloniale onderdane om teen Duitsland te veg. Heelwat van hierdie Boere demonstreer hulle protes via 'n organisasie wat as die Ossewa Brandwag (OB) bekend gestaan het. Stoker was 'n kommandant in dié beweging. (Besonderhede oor die OB word bewaar in 'n OB-uitstalling in die Ferdinand Postma-biblioteek van die Potchefstroom Kampus van die Noordwes-Universiteit asook die OB-versameling in die argief van dieselfde kampus.) 
Op 21 Desember 1942 word Stoker (as gevangene nr. K2231/42) in die Koffiefonteinse interneringskamp vir 'n jaar agter tralies en doringdraad toegesluit. Dit het heel waarskynlik gebeur as gevolg van sy negatiewe siening van die Smuts-regering se deelname aan WOII. In sy Stryd om die ordes (Stoker 1941a:272-273) het Stoker volgens die veiligheidspolisie van die Smuts-bewind te veel begrip vir die ontstaan van die Duitse Nasionaal-Sosialisme openbaar. (Vir besonderhede oor die redes vir Stoker se inhegtenisneming en sy politieke standpunt vgl. Van der Schyff 2003:504-505, 520-522). Die boek Agter tralies en doringdraad (BOGP 1953:1-82) bied ook volledige besonderhede oor die omstandighede in Suid-Afrika tydens WOII. Stoker (1953:306-325) het self 'n bydrae tot hierdie bundel gelewer waarin hy - tipies filosofies - die sosiologiese, psigologiese en etiese aspekte van die Koffiefonteinse boerekamp analiseer.

Dit is merkwaardig hoe die geïnterneerdes hulle gevangenisskap nuttig gebruik het. Stoker word rektor van die 'Kampuniversiteit' en gee vir die ander klas. Een van sy studente was Jan A.L. Taljaard wat as gevolg van sy OBaktiwiteite reeds op 06 Februarie 1942 'n politieke gevangene geword het en nog langer as Stoker - tot November 1944 daar sou bly. Taljaard sou later (in 1945) sy BA-studies aan die Puk voltooi, sy meestersgraad onder leiding van Stoker (in 1947) behaal en hy het ook Stoker se kollega in filosofie geword (vgl. Kruger 1975:230).

Terugskouend spreek De Klerk (1991) die volgende oordeel oor die OB uit:

Die aktiewe deelname van verskeie Potchefstroomse akademici aan die OB en die vorming van sy ideologie het die lewensbeskoulike rigting wat hierdie universiteit verteenwoordig het, nie ten goede gekom nie... Hoewel Calvinistiese denkers gehelp het om ekstreem Fascistiese beskouings teen te gaan en hulle ' $n$ matigende rol gespeel het, het hulle hul te veel laat meesleur deur die heersende tydsgees en die Calvinistiese denke sterk omgebuig om daarby aan te pas eerder as om 'n sterk kritiese invloed te laat geld. (bl. 323)

Ruimte laat dit nie toe om hier in te gaan op die rol van die Afrikaner Broederbond (tans net Afrikanerbond), wat reeds in 1918 gestig is nie. Hoewel Smuts en die Afrikaner Broederbond ( $\mathrm{AB}$ ) ook aardsvyande was, het hy nie teen sy lede opgetree soos teen dié van die OB nie (vgl. Smith 2009:19 e.v. vir'n kort geskiedenis van die AB).

\section{'n Verdediger van afsonderlike ontwikkeling}

Stoker moes in uiters moeilike tye dus telkens 'n keuse maak tussen verskillende ideologieë en lewensvisies, sy standpunt filosofies regverdig en het so ook leiding aan sy volksgenote gegee. Hierdie ideologieë was egter nie onskuldige teoretiese sake nie: die Britse Imperialisme het tot die AngloBoereoorlog gelei; die Duitse Nasionaal-Sosialisme tot 'n botsing met die Anglo-Amerikaanse liberalisme in WOII; die republikeinse vryheidstrewe van die Afrikaner (teenoor Engelse kolonialisme) het van Stoker self 'n politieke gevangene gemaak.
Dit hoort tot die ironie van die geskiedenis dat Stoker later (vgl. 'Vier moontlike oorsake by Stoker self') die ideologie van apartheid verdedig het. Nadat die Britse gevaar van die toneel verdwyn het, is hy met die 'Swart gevaar' gekonfronteer. Ter versagting moet gesê word dat Stoker nie 'n uitsondering was nie - die meeste ander dosente aan die Puk het tot op 'n sekere punt in die geskiedenis sy standpunt in hierdie verband gedeel. Slegs 'n jaar na sy dood sou daar egter ' $n$ nuwe bedeling vir sy land aanbreek - 'n land sonder apartheid, maar nie een sonder ander, nuwe probleme nie. Daarom dus 'n land waarin die goeie in sy filosofiese nalatenskap vandag nog lewend gehou behoort te word.

\section{Erkenning - en vrugte tot in sy ouderdom}

Ten slotte word die aandag gevestig op die feit dat Stoker tydens sy lewe wel erkenning vir sy werk ontvang het. Hy word byvoorbeeld in 1963 uitgenooi om gaslesings aan die Vrije Universiteit en in 1973 by Dordt College in die VSA aan te bied. In 1964 ontvang hy die Stalsprys vir Filosofie van die Suid-Afrikaanse Akademie vir Wetenskap en Kuns. In 1964 (nadat hy vir 40 jaar, vanaf 1924 tot 1964, aan die Puk verbonde was) emeriteer hy, maar word herbenoem tot 1969. In 1970 word hy ereprofessor aan die Randse Afrikaanse Universiteit (tans die Universiteit van Johannesburg). Op 24 April 1971 ontvang hy die hoogste erkenning, naamlik 'n eredoktorsgraad van die Puk.

Die skrywer het die voorreg gehad om by Stoker voorgraadse klas te loop en (as enigste honneursstudent in Filosofie) ook tuis in sy studeerkamer aan sy voete te sit (vgl. Van der Walt 1993). In later jare het dit my getref hoe hy - man alleen - as redakteur van die Bulletin van die Suid-Afrikaanse Vereniging vir die Bevordering van Christelike Wetenskap elke uitgawe van hierdie blad beplan, versorg en telkens 'n borg vir die drukkoste daarvan gevind het. Hy het inderdaad tot in die gryse ouderdom vrugte gedra (Ps. 92:13-15).

\section{Moontlike lewensbeskoulik- filosofiese invloede op die denke van Stoker}

Te midde van al bogenoemde politiek-sosiaal-kulturele omstandighede en sy vele bedrywighede word Stoker se eie filosofie ook gebore. In hierdie gedeelte, wat die hoofdeel van hierdie bydrae uitmaak, word die vraag gestel, naamlik watter verskillende faktore spesifiek op die ontstaan van sy filosofie 'n invloed kon gehad het.

\section{Stoker self lig die sluier}

Gelukkig hoef ons nie oor die vormende faktore op die denke van Stoker te gis nie. In Stoker (1970:218-219, 332-336) lig hy die sluier oor die historiese agtergrond van sy eie denke. Hy noem eers die name van die Calvinistiese teoloë, naamlik A. Kuyper (Snr), J. Woltjer, W. Geesink, V. Hepp en veral H. Bavinck. Dan noem hy die naam van sy promotor in Duitsland, Max Ferdinand Scheler. 
Uit wat daarop volg, blyk dit dat die twee denkers waarvan hy die meeste geleer het die gereformeerde teoloog, Bavinck, en die fenomenologiese wysgeer, Scheler was. Hy sê (vgl. Stoker 1970:334) dat hy na sy benoeming as dosent aan die Puk in 1925 aanvanklik grotendeels volgens die rigting van Bavinck gefilosofeer het, maar dat kennismaking met die geskrifte van Vollenhoven en daarna van Dooyeweerd hom talryke en fundamentele nuwe insigte besorg het.

'n Mens sou dus die verskillende invloede op Stoker se filosofie breedweg kon verdeel as invloede van binne eie Calvinistiese, geesgenootlike kring (eers meer teologies en later meer filosofies) en die invloed van buite hierdie kring (Scheler was nie 'n Calvinis nie en het in 1921 ook van sy lidmaatskap aan die Roomse Kerk en selfs sy geloof in God afstand gedoen).

Natuurlik is so 'n indeling (van binne en buite) kunsmatig. Verder moet in gedagte gehou word dat ons hier nie met 'n eenvoudige legkaart te make het nie. Om presies te bepaal watter invloed(e) op watter faset van Stoker se denke 'n rol gespeel het en hoe sterk of swak dit was, is moeilik, dalk selfs onmoontlik, bepaalbaar. Dit sou deeglike navorsing verg waarin byvoorbeeld die werke van Bavinck en Scheler met die hele oeuvre van Stoker vergelyk moet word - iets waarvoor 'n enkele, oorsigtelike artikel soos hierdie in elk geval onvoldoende ruimte bied.

Wat hier volg, is dus slegs enkele flitse en fragmente van moontlikhede. Eers word gelet op moontlike invloede vanuit eie geesgenootlike kring en daarna op dié van veral die fenomenologiese denke.

\section{Invloede vanuit eie geesgenootlike kring}

Dit moet in gedagte gehou word dat Stoker reeds lewensbeskoulik toegerus was toe hy besluit het om in die buiteland verder te gaan studeer. In Suid-Afrika was die Calvinistiese lewensvisie bekend by 'n groot deel van die destydse Afrikanergemeenskap - ook Kuyper en Bavinck was nie onbekende name nie (vgl. Van der Walt 1980).

'n Mens sou egter kon sê dat hierdie lewensvisie van die jeugdige Stoker hoofsaaklik op teologiese gebied wetenskaplik uitgewerk is. Die jong Stoker se ideaal was om vas te stel wat dit op filosofiese terrein sou impliseer. Die vorm wat die Suid-Afrikaanse Calvinisme aangeneem het, sou egter 'n blywende invloed op Stoker se denke hê. Daarom moet hier kortliks iets meer daaroor gesê word.

\section{Die invloed van die Suid-Afrikaanse gestalte van die Calvinisme}

Die soort Calvinisme waarin Stoker grootgeword het, was dié van 'n Christelik-Nasionale ideaal. (Dit het byvoorbeeld duidelik gestalte gevind in die idee van Christelik-nasionale onderwys.) In sy boek Die stryd om die ordes (Stoker 1941a:274-275) onderskei hy tussen drie tipes Christeliknasionale denke: 'n meer liberalistiese en 'n meer sosialistiese tipe - die twee uiterstes wat die klem óf op die individu óf op die volk gelê het - en die korrekte tipe wat die balans tussen die twee uiterstes handhaaf.

Die groot probleem ten opsigte van die verhouding tussen die twee pole van die Christelike aan die een kant en die nasionale aan die ander kant bespreek hy egter nie. Heel waarskynlik is dié verbondenheid as vanselfsprekend deur sy voorgangers, tydgenote en homself aanvaar.

In die koppeling van 'Christelik' met 'n asionaal' lê egter juis die probleem. Heel waarskynlik het die oplossing vir Stoker ook in die balans of ewewig tussen die twee gelê. In Stoker (1941a) huiwer hy egter nie om die nasionale voorop te stel nie en skryf selfs:

... wie meen dat ons met die volksbeklemtoning (wat nog geen volksvergoding is nie) ons ander beginsels prysgee en nie op die aangewese tyd weer opnuut gaan beklemtoon nie, vergis hom (bl. 271 e.v.).

Hieruit blyk reeds duidelik dat werklik integrale Calvinisme nie Christelik-nasionaal kan wees nie. Dan word dit op 'n prinsipieel-onversoenbare dualisme gebou, sodat die balans waarna gestreef word slegs 'n droom bly. Van der Walt (1995:16-21) het die onversoenbare gespletenheid en spanning tussen die twee pole aangetoon. Daar sou selfs beweer kon word dat dit Stoker se klem op die nasionale pool was wat hom verhinder het om te kon insien dat ' $n$ ideologie van apartheid tussen verskillende volke in dieselfde land verkeerd is.

In alle geval moet die Suid-Afrikaanse vorm van ('n taamlike politiek-gekleurde) Calvinisme as die eerste voedingsbodem van sy denke beskou word. Met die Nederlandse (teologiese) Calvinisme van Kuyper en Bavinck het hy ook reeds in SuidAfrika kennis gemaak, maar daaroor sou hy graag meer wou leer (vgl. 'Die Anglo-Boereoorlog en WOI'), veral ten opsigte van die filosofiese implikasies daarvan.

\section{Intermezzo: Versigtigheid nodig}

Voordat verdere moontlike invloede op die filosofie van Stoker nagegaan word, moet die volgende steeds in gedagte gehou word.

In die eerste plek moet onthou word dat hy, behalwe 'n (hoofsaaklik polities en teologies vergestalte) Calvinistiese lewensvisie, nog nie 'n Christelike filosofie as hulp tot sy beskikking gehad het nie - hy moes dit nog (help) uitbou en dit was nie 'n eenvoudige taak nie.

In die tweede plek is dit makliker om vandag - na meer as 80 jaar - gebreke in iemand se denke raak te sien. Daarom moet dit met versigtigheid en nie veroordelend gebeur nie.

In die derde plek laat die inleidende en oorsigtelike karakter van hierdie artikel alleen toe dat daar enkele vermoedens is of vrae gestel word oor moontlike invloede by Stoker. Sou die presiese gewig van die verskillende invloede ook nog nagegaan moes word, sou die ondersoek die formaat van 'n proefskrif moes aanneem. Soos reeds gesê, wil hierdie verkenning slegs as stimulus vir verdere spoorsnywerk dien. 
Vierdens is dit ook onmoontlik om in 'n artikel met beperkte lengte ook nog die probleem van 'n waarskynlike ontwikkelingsgang in Stoker se denke onder oë te neem.

In die vyfde plek moet gevra word volgens watter maatstaf die invloede as goed, minder goed of dalk skadelik beskou behoort te word - selfs nadat dit aangetoon is. Indien 'n mens byvoorbeeld van mening is dat enige denkbeeld deur 'n Christelike filosofie oorgeneem mag word, sou daar geen probleem bestaan nie. Dan sou sintese of akkommodasie iets goed wees. Indien 'n mens, soos Stoker self wou doen, 'n werklike Christelike filosofie op grond van God se openbaring wil uitbou, behoort daar egter uiters versigtig te werk gegaan word, omdat religieuse en lewensbeskoulike oortuigings ook 'n mens se filosofiese denke grondig beïnvloed.

Ten slotte moet - en dit is baie belangrik - onthou word dat Stoker nie 'n blote naprater nie, maar 'n selfstandige en oorspronklike denker was. Stoker sê byvoorbeeld (vgl. Stoker 1970:333) van Scheler se invloed op sy denke dat hy heelwat van sy gedagtes as onaanneemlik beskou het. Tog is sy insigte nie op louter valsheid gegrond nie. Scheler se insigte wou Stoker dus eers losgewikkel uit hulle verband en onaanvaarbare grondslae. Soos verder sal blyk, is dit egter nie maklik om vas te stel op watter punte Stoker met byvoorbeeld Bavinck en Scheler saamgestem en op watter punte hy van hulle verskil het nie. Die aandag val nou eers op Bavinck.

\section{Die moontlike invloed van Bavinck (1854-1921)}

Stoker self help ons om moontlike beïnvloeding deur Bavinck op te spoor. Hy sê byvoorbeeld (vgl. Stoker 1970:335) dat hy geworstel het met die vraag hoe 'n waarlik Calvinistiese wysbegeerte moontlik kon wees wat nie op 'n (verkapte) teologie sou neerkom nie. Hy sê dat hy in hierdie verband veel van Vollenhoven kon leer, maar dat hy die taak en veld van die wysbegeerte en teologie meer in die lyn van Bavinck se denke sien.

\section{Wat Stoker van Bavinck kon leer}

Ek is van mening dat Stoker juis op hierdie punt sterk deur Bavinck beïnvloed is. Ons vind na aanleiding van Vollenhoven (2011:212-214) se lesing oor teologie en filosofie 'n diskussie (uit 1963) tussen Vollenhoven en Stoker waaruit duidelik blyk dat hulle heeltemal verskillende standpunte in dié verband gehuldig het.

Stoker (1970:333) noem verder die volgende wat hy van Bavinck kon leer: Eerstens, Bavinck se insig dat openbaring alles ten grondslag lê en dus as basis vir 'n Calvinistiese kenleer kan dien. (Stoker sluit daarby met sy fenerotiese metode aan.) Tweedens, Bavinck se ontologie van God, mens en wêreld of God en kosmos. Derdens, sy visie op die mens as kroonpunt van die kosmos en in die vierde plek, sy klem op beginsels. Laastens kan Bavinck se visie op die velde van ondersoek vir teologie en wysbegeerte ook bygevoeg word.

\section{Bavinck se positiewe bydrae}

Waarom Stoker graag onder Bavinck sou wou promoveer, kan verklaar word uit die volgende positiewe opmerkings van Vander Stelt (2012). Veral later in sy lewe wou Bavinck as hervormer uit sy beperkte kerklik-teologiese tradisie breek om breër te kyk. Teenoor die liberalisme van sy tyd het hy gepleit vir die terugkeer na God en sy Woord. Teenoor die piëtisme in sy eie geledere het hy ook sy mense opgeroep om meer in die wêreld rondom hulle betrokke te raak. Dit was onder andere moontlik deur sy Calvinistiese beklemtoning van die Bybelse gedagte van religie as iets sentraal, 'n hartrespons op God se alles-deurdringende openbaring. Hierdie gedagtes moes Stoker beslis aangetrek het.

Bavinck was dus konfessioneel regsinnig en gereformeerd, maar, so skryf Vander Stelt (2012), die filosofiese grondslae van sy teologie het hom telkens in sy reformatoriese ideaal gekortwiek. Hy is filosofies sterk beïnvloed deur die Protestantse en selfs Roomse skolastiek.

\section{Bavinck se ontologie}

Aangesien 'n mens se visie op die werklikheid of ontologie bepalend is vir die res van sy denke, word eers iets daaroor gesê. Bavinck se basiese onderskeid is dié tussen God-menskosmos. Word 'mens' as 'n deel van die kosmos beskou, dan bly vir Bavinck uiteindelik net twee werklikhede oor, naamlik God en kosmos. Hy huldig dus 'n twee-faktor of dualistiese ontologie (vgl. Bavinck 1908:17-18, waar Bavinck Skepper en skepping onderskei: God is transendent, maar nie van die kosmos geskei nie. Hy is ook immanent in die skepping).

Bavinck (1906:212-213) noem God se wette principia (beginsels) en onderskei tussen 'n principium essendi (in die bewussyn van God), 'n principium cognoscendi externum (in die geskape dinge) en 'n principium cognoscendi internum (die menslike rede of logos as kenbeginsel). Volgens laasgenoemde moet die mens die wette of logoi (redekieme) wat God volgens die beginsels in sy eie verstand in die kosmiese dinge ingeskep het, abstraheer om tot ware kennis te kom (vgl. ook Van der Walt 1953 vir meer detail).

\section{Thomistiese invloede}

Iemand wat op hoogte is met die geskiedenis van die Westerse denke, sal dadelik besef dat hierdie soort filosofiese ontoloige ontleen is aan die Thomistiese denke. Thomas van Aquino (1224-1274) onderskei ook net tussen God en kosmos en hy plaas die wette (of wat Bavinck 'beginsels' noem) ante rem in God, in rebus in die geskape werklikheid en post rem in die menslike rede.

Dit is bekend dat die logosspekulasie by die figure wat Stoker noem (bv. Woltjer, Hepp asook Bavinck) 'n belangrike rol gespeel het. Soos hierbo genoem, is God die hoogste Logos wat die logoi spermatikoi (redekieme) in die dinge inskep, wat dan deur die mens se logos (rede) uit die dinge geabstraheer 
word om logiese kennis te bereik. Deur die goddelike kieme in die skepping openbaar God homself. Hierdie goddelike openbaring (in die dinge en in die menslike verstand) verseker dat daar ooreenstemming tussen die kenbare en die kenresultaat by die kenner sal wees, dat ware kennis gevind is.

Hierdie skolastieke invloede op Bavinck is deur talle latere teoloë erken. So byvoorbeeld deur Bremmer (1961:328) wat skryf dat Bavinck veral by die herleefde neo-skolastiek van die $19 \mathrm{e}$ eeu en spesiaal by Matteo Liberatore, aansluit. Ook Veenhof (1968:628) vestig die aandag op die duidelike Thomistiese filosofiese substraat van belangrike dele van Bavinck se dogmatiek. Indien in gedagte gehou word dat die neo-Thomisme 'n herlewing inhou van die denke van die Middeleeuse denker, Thomas van Aquino, word die verdere lyne terug in die geskiedenis ook helder. As gevolg van Thomas se reeds vroeëre akkommodasie van die denkgoed van die pagane Griekse denker Aristoteles, is Liberatore se groot liefde vir die Stagiriet ook verklaarbaar.

Indien 'n mens let op die baie kere wat Bavinck (1906) met instemming regstreeks na Thomas van Aquino se geskrifte (bv. sy Summa Contra Gentiles en Summa Theologica) verwys, hoef Liberatore egter nie eers as tussenskakel genoem te word om die duidelike Thomistiese invloed op Bavinck se denke te bevestig nie. Vergelyk ook Vollenhoven (1982:105) dat Bavinck 'n skolastieke, platoniserende subsistensieteorie in die lyn van Boethius, Albertus Magnus en Suarez voorgestaan het. Ook in sy mensbeskouing sluit Bavinck dus by Thomas se subsistensieteorie aan. Daarvolgens bestaan die mens uit twee afsonderlike substansies, naamlik 'n hoëre siel en 'n laere liggaam (vgl. Fernhout 1975:10 e.v.).

In Vollenhoven (2000:257) word die filosofie van Bavinck, as grondslag van sy teologie, soos volg beskryf: Hy hoort tot die finale neo-idealistiese stroming binne die latere rasionalisme. Sy tipe filosofie word volgens Vollenhoven se probleem-historiese metode beskryf as louter kosmologies, dualisties, 'n Aristoteles-interpretasie, vertikale gedeeltelike universalisme en Platoniserende subsistensieteorie.

\section{Natuur-genade-tema}

Die Thomistiese natuur-genade tema speel by Bavinck ook 'n rol (vgl. Bavinck 1906:193). Net soos Thomas leer hy dat die natuur 'n voortrap tot die genade is en die genade die natuur vervolmaak (vgl. Bavinck 1906:336: natura praecedit gratiam, gratia perfecit naturam).

Hierdie dualistiese visie lei tot 'n tweedeling tussen wete en geloof: ratio perfecitur a fide, fides supponit naturam. Heideman (1959:132, 196) vestig nie alleen die aandag daarop dat Bavinck 'n onderskeid tref tussen die natuur-genade en wete-geloof nie, maar sê dat dit 'n sentrale gedagte vorm wat deur Bavinck se hele teologie loop.

Daar moet wel gesê word dat Bavinck die tema van natuur en genade probeer modifieer het om sy eie posisie teenoor dié van Thomas (of die Roomse kerk), die Anabaptisme en
Lutheranisme duideliker af te baken (vgl. Veenhof 1968: 345-356, 1994). Ek kry die indruk dat Bavinck nie so sterk as by Thomas 'n ontologiese vervolmaking van die natuur deur die genade gehuldig het nie, maar meer 'n religieuse vernuwing - 'n meer Bybelse visie dus. Die regte oplossing sou myns insiens egter gewees het om die hele natuur-genade en geloof-wete dualisme te verwerp.

\section{Kenteorie}

Bavinck (vgl. Stoker 1941b:140-149) lê groot klem op God se omvattende openbaring. Hy sê byvoorbeeld: 'De gansche wêreld rust zelve in openbaring; openbaring is de grondslag, het geheim van heel de schepping ...' (Bavinck 1908:23). Veenhof (1968) het Bavinck se openbaringsfilosofie in detail geanaliseer en die aandag op belangrike probleme in dié verband gevestig. Ek wil hier alleen benadruk dat Bavinck se dualisties-georiënteerde filosofie (soos hierbo beskryf) ook aanleiding gee tot sy onderskeid tussen 'n revelatio naturalis en supranaturalis. (Bavinck se kenteorie word dus deur sy voorafgaande ontologiese en antropologiese uitgangspunte bepaal.)

\section{Bavinck oor teologie en filosofie}

In ooreenstemming met tweërlei openbaring en sy redegeloof onderskeid aanvaar Bavinck ook twee teologieë: 'n theologia naturalis (waarin die rede belangrik is) en 'n theologia supernaturalis (waarin geloof ter sprake kom). Laasgenoemde is 'n studie van God soos Hy Homself in sy Woord geopenbaar het, terwyl eersgenoemde die skepping in sy verhouding tot God bestudeer. Anders geformuleer: laasgenoemde, deur Bavinck Heilige Godgeleerdheid genoem, bestudeer die wese van God en eersgenoemde sy werke.

Let daarop hoe Bavinck se filosofiese ontologie van God en kosmos ook sy visie op die teologie bepaal. Let ook daarop hoe Bavinck hom in sy Gereformeerde Dogmatiek vir sy siening telkens op Thomas van Aquino as outoriteit, asook op verskillende denkers uit die sewentiende-eeuse Gereformeerde Skolastiek beroep.

Behalwe die bonatuurlike (Christelike) teologie (heel bo) en die natuurlike teologie (daaronder), erken Bavinck ook nog die bestaansreg van filosofie (heel onderaan). Laasgenoemde bestudeer die natuur van alle kosmiese dinge. Eersgenoemde gaan oor God en het met die geskapene alleen te make in soverre hulle God se werke is en iets van Hom openbaar (vgl. Bavinck 1906:501). Die natuurlike teologie handel dus oor die skepping in soverre dit na God verwys.

\section{Gevolgtrekking}

Na die voorafgaande kan die (negatiewe) waardering van Bavinck se denke deur Vander Stelt (vgl. hierbo) nie ontken word nie. Bavinck was nie genoegsaam bewus van die gevare van die sintesedenke van die Thomisme en Thomistiesgekleurde Gereformeerde Ortodoksie van ongeveer 1550 1700 en selfs daarna nie. Dit het sy reformatoriese bedoeling ongelukkig ernstig belemmer. 


\section{Die nawerking van Bavinck se invloed op Stoker}

In die lig van wat so pas oor Bavinck se denke vasgestel is, moet ongelukkig ook van Stoker gesê word dat sy aanleun teen verskeie fasette van Bavinck se denke die reformatoriese suiwerheid en élan van sy filosofie kon gedemp het. Met die kort skets van Bavinck se denke kan die leser self maklik parallelle in Stoker se filosofie opspoor. Ek gee dus slegs enkele voorbeelde:

\section{Tweefaktor ontologie se implikasies}

In sy opstel 'God (Theos) en wêreld (kosmos)' (Stoker 1970:9 e.v.) blyk nie alleen dat Stoker 'n soortgelyke (tweefaktor) ontologie as Bavinck huldig nie, maar dit blyk ook reeds op die eerste bladsy wat die implikasies daarvan vir sy visie op die velde van ondersoek vir teologie en filosofie is: Die teoloog bestudeer in die eerste plek die geopenbaarde waarhede aangaande God in sy Woord en in die natuur, en sy verhouding tot die kosmos, terwyl die wysgeer in die eerste plek die kosmiese werklikheid ondersoek (vgl. ook later in Stoker 1970:91, 106 waar hy sy standpunt herhaal, asook Stoker 1967d:84, 225 en talle ander plekke).

Dit wil lyk of al verskil tussen Stoker en Bavinck is dat Stoker nie, soos Bavinck, by die teologie langer 'n onderskeid tussen 'n bonatuurlike en natuurlike teologie maak nie. Stoker vat wat Bavinck onderskei het (God se openbaring oor homself as veld vir 'n bonatuurlike teologie en sy verhouding tot die kosmos as 'n natuurlike teologie) saam tot die dubbele veld van één teologie.

Aangesien daar vanuit die ander kringe van die reformatoriese filosofie in Nederland en elders reeds indringende kritiek op Stoker se visie op die onderskeie take van filosofie en teologie gelewer is, word hier nie verder daarop ingegaan nie. Veral Stoker se gedagte dat ander Christenwetenskaplikes (filosowe ingesluit) nie selfstandig 'n eie eksegese van die Skrif mag maak nie, maar dit van die teologie moet leen, is wyd en skerp in dié tradisie veroordeel. Dit skep die indruk dat Stoker sy Christelike filosofie op 'n Christelike teologie wou fundeer, terwyl ander reformatoriese denkers presies die omgekeerde beklemtoon het, naamlik dat elke teologie nolens volens van filosofiese vooronderstellings uitgaan.

\section{Mensbeskouing}

Hoe kunsmatig Stoker se onderskeid tussen 'n Christelike teologie en filosofie kan word, blyk byvoorbeeld daaruit wanneer Stoker $(1967 d: 84,99)$ oor die beeld van God in die mens skryf en dan beweer dat die mens as beeld van GOD 'n teologiese vraagstuk is, terwyl die mens as BEELD van God 'n wysgerige sou wees.

Uit dieselfde opstel oor die mens as beeld van God blyk ook duidelik hoe Stoker deur die Thomistiese leer van die analogia entis beïnvloed is. Die beeldskap van God sou volgens hom wel nie op 'n egte analogiese verhouding tussen God en mens dui nie, maar dit bly nogtans 'n soort analogie. Nuwere insigte in die Skrif toon egter aan dat so 'n visie op die beeldskap nie volgens die Bybel regverdigbaar is nie (vgl. Van der Walt 2010a:325 e.v.)

\section{Openbaringsidee}

'n Mens sou verder kon nagaan wat die invloed van Bavinck se klem op openbaring (vgl. hierbo) was op Stoker se denke en veral op sy (dia)fenerotiese metode, asook hoe Scheler se idee van die openbaringskarakter van fenomene daarmee gekombineer is. 'n Wye veld van navorsing lê vir die geïnteresseerde student hier nog braak. Die hoofbedoeling daarvan behoort nie te wees om Stoker net te kritiseer nie, maar om - staande op sy skouers - die taak van voortdurende reformasie van die Christelike filosofie voort te sit.

Ons kan nou oorgaan na 'n volgende faset, naamlik die moontlike invloede op Stoker van buite sy eie geesgenootlike kring. Die belangrikste in hierdie verband is seker die volgende:

\section{Moontlike invloed van Scheler (1874-1928)}

Op die Wikipedia webtuiste word kernagtig op Scheler se lewe en denke ingegaan. Aangesien my eie kennis van Scheler se denke uiters beperk is, sal ek hier hoofsaaklik op sekondêre bronne oor sy filosofie moet staatmaak en is dit nie gewens om, soos in die geval van Bavinck hierbo, moontlike belangrike ooreenkomste en verskille tussen die filosofie van Scheler en Stoker aan te toon nie. Hopelik sal die bronne wat hier genoem word vir die belangstellende student van hulp wees om hierdie kort oorsig verder tot 'n verdiepte vergelyking te voer. (Op Wikipedia webtuiste word nie alleen 10 primêre (in Engels vertaalde) werke van Scheler genoem nie, maar ook ongeveer 16 sekondêre bronne oor sy filosofie.)

\section{Stoker se eie getuienis}

Volgens Stoker (1970:333-334) kon hy veral die volgende twee dinge by sy promotor leer: Eerstens sy waardeleer (vgl. Scheler 1955), wat moontlik daartoe gelei het dat Stoker later 'n afsonderlike kosmiese dimensie van waardes erken het. In die tweede plek Scheler (en ook Husserl) se fenomenologiese metode. Volgens Stoker het hy nie net sy 1925-proefskrif daarvolgens geskryf nie, maar dit daarna nog steeds gebruik. Dit behoort, volgens hom, nie afgewys te word nie, omdat Husserl en Scheler met die gebruik daarvan van foutiewe veronderstellings uitgaan nie. Stoker beskou dié metode as een van die diafenerotiese of openbarende metodes.

Aangesien ek reeds een en ander oor waardes en ook Stoker se visie daarop geskryf het (vgl. Van der Walt 2010b, 2010c), word dit hier oorgeslaan en slegs oor Scheler (en terloops ook Husserl) se filosofie in die algemeen en sy fenomenologie in die besonder, word iets gesê.

\section{Scheler se filosofie in die algemeen}

Vollenhoven (1982:101), wat 'n noue verband tussen die denke van Stoker en dié van Bavinck en Scheler vermoed, bied die volgende basiese tipering van Scheler se denke (vgl. Vollenhoven 1982:75, 2000:245, 247). Wat die normatiewe rigting van sy filosofie betref, was Scheler (net soos Husserl) eers 'n laat-rasionalistiese, meer spesifiek neo-idealistiese denker, maar aanvaar reeds vanaf 1910 die lewensfilosofie, 
'n eerste stroming binne die irrasionalisme. Die tipe filosofie (oor die struktuur van die werklikheid) wat hy gehuldig het, bly egter kosmogono-kosmologies en monisties. In dié opsig verskil hy van Bavinck wat louter-kosmologies en dualisties gedink het. Wat sy mensbeskouing betref, ruil hy egter sy antropologiese wisselwerkingsteorie in vir ' $n$ ennoëtistiese prioriteitsleer. Die prysgewing van sy Christelik-Katolieke oortuigings in 1921, lei in sy latere lewe ook daartoe dat hy in die vaarwaters van 'n monistiese panteïsme eindig. (Dit is terloops interessant dat Vollenhoven aan Husserl, ten minste gedurende die eerste fase van ontwikkeling, dieselfde tipe filosofie as dié van Bavinck toeskryf.)

Die implikasies van Scheler se verskuiwing van rasionalisme na irrasionalisme was belangrik vir sy kenteorie. Tydens die rasionalistiese fase het die waarborg vir die sekerheid van menslike wetenskaplike kennis vir Scheler in die menslike rede (die subjek) gelê. As irrasionalis devalueer hy die rede en lê hy die klem op die objek van kennis, die konkrete werklikheid - in die geval van die lewensfilosofie op die lewe, gevoel en mag. Ook nie meer deur middel van denke nie, maar deur 'n gevoel van liefde, word kontak tussen subjek (kenner) en objek (werklikheid) gemaak. Die objek openbaar dan sy wese aan die kenner wat die selfevidente (d.w.s nie redelik bewysbare) wesenskou daarvan moontlik sou maak (vgl. Spier 1959:197-199 se kort beskrywing).

In die geval van Stoker vind ons 'n soortgelyke tendens om teenoor die rasionele kenner die kenbare werklikheid sterker te beklemtoon om so 'n beter balans tussen die subjek en die objek van kennis te bereik.

\section{Scheler se fenomenologiese metode}

Soos reeds gesê, noem Stoker dat hy sy 1925-proefskrif onder leiding van en volgens Scheler se fenomenologiese metode geskryf het en dat hy daarna nog steeds van die metode gebruik gemaak het. Stoker (1967b) se latere werk oor 'n fenomenologiese analise van die gewete kan beskou word as 'n samevatting van sy proefskrif, sodat diegene wat nie Duits magtig is nie, dit kan gebruik om Stoker se gebruik van die fenomenologiese metode te verstaan. Daarin noem hy ook uitdruklik dat die metode sy oorsprong by Husserl en Scheler vind.

Gelukkig beskik ons vandag, behalwe oor die reeds genoemde in Engels vertaalde werke van Scheler, ook oor goeie sekondêre bronne wat handel oor hierdie metode van die genoemde twee denkers, naamlik dié wat in die algemeen oor die fenomenologie handel (bv. Van Peursen 1967, 1968; Lauer 1965); en dié wat handel oor die fenomenologiese metode (Bochenski 1954:22-34). Meer detail word gebied in Bakker 1966:69 en verder oor Husserl; 109 en verder oor Scheler; Spiegelberg 1969:73 en verder oor Husserl; 228 en verder oor Scheler; De Boer 1968, 1977 oor Husserl; en Husserl 1964.

\section{Stoker self oor die fenomenologiese metode}

'n Vraagstuk waarop hier nie ingegaan kan word nie, is of Stoker sedert omstreeks 1933 van kenteoretiese standpunt verander het (vgl. Stoker 1933b) en of dit wat hy daaroor geskryf het, versoenbaar is met sy fenomenologiese metode. In 1933 skryf hy dat die kenbare deur middel van ingressiekanale die bewussyn (rede) binnekom en op dié wyse geken word. Volgens sy fenomenologiese metode openbaar die kenbare dinge egter hulle wese aan die kenner. Volg die fenomenologiese proses op dié van ingressie of is hier van twee verskillende metodes sprake?

'n Tweede probleem is die onduidelikheid by Stoker tussen die fenomenologiese metode in die algemeen en Stoker se eie (dia)fenerotiese metode as ' $n$ vorm van die fenomenologiese metode. Ons laat die probleme egter daar en gee 'n kort uiteensetting van hoe Stoker sy metode beskryf.

In die genoemde artikel bied Stoker (1967b:305-308) die volgende beskrywing van sy metode. Dit soek na die kern of wese van ' $n$ bepaalde individuele fenomeen of verskynsel iets wat hy erken as moeilik omskryfbaar. Teenoor rasionele observasie moet hierdie metode dus van intuïsie gebruik maak. Deur middel daarvan word die buitekant van ' $n$ verskynsel afgestroop om by die binnekant of wese daarvan uit te kom. Stoker (1967b:308) verwys na Husserl wat die term Einklammerung of tussen hakies plaas, gebruik. Stoker beklemtoon dus dat, om die metode te gebruik, alle vooraf kennis, teorieë en vooroordele wat 'n mens aangaande die fenomeen mag hê, opsy geskuif of tussen hakies geplaas moet word, sodat die fenomeen self kan praat. Die fenomeen moet dus toegelaat word om vir homself te getuig, sy wese aan die kenner te openbaar. Hierdie oerfenomeen wat aan jou openbaar word, sê Stoker, kan op geen direkte wyse beskryf word nie. Dit kan alleen op 'n indirekte manier aanskou word, sodat logiese begronding of geldigheid nie by hierdie metode van toepassing is nie: 'The self-evidence of the characteristics thus indirectly revealed and described, is the only proof the phenomenologist can and intends to give' (Stoker 1967b:308).

\section{Kort kommentaar}

Heelwat vrae kan in die verband aan Stoker gestel word. Van der Walt, (2009:71-72) het nog heelwat meer vrae en Van der Hoeven $(1963,1965)$ bied verdere indringende kritiek op die fenomenologiese denke vanuit 'n reformatoriese perspektief.

In die eerste plek is dit natuurlik waar dat 'n mens nie net op logiese wyse kennis kan verwerf nie. Jy kan ook op intuïtiewe etiese, tegniese, juridiese, ekonomiese, sosiale en religieuse wyse verskillende soorte kennis bekom. 'n Mens ken nogtans altyd as hele mens, sodat nie een van hierdie maniere van kennis geïsoleer kan word van die logiese element van ken nie.

In die tweede plek kan aan Stoker die vraag gestel word of die tussen hakies plaas van eie vooraf kennis en vooronderstellings nie 'n neutrale benadering impliseer nie - iets wat direk bots met Stoker se eie standpunt dat neutrale wetenskapsbeoefening onmoontlik is.

Derdens kan gevra word of dit korrek is om aan geskape dinge 'n eie openbaringskrag toe te skryf. Is die bybelse 
standpunt nie dat God alleen kan openbaar en dit doen deur die skepping nie? Stoker se simpatie met Bavinck se filosofie van God se universele openbaring het in dié verband heel waarskynlik Scheler se idee versterk dat 'n fenomeen oor openbaringskrag beskik.

My volgende kommer oor Stoker se aanvaarding van die fenomenologiese metode - ek bemerk op die oog af nie veel verskil tussen sy eie gebruik daarvan en dié van Scheler nie-is dat dit, op tipies irrasionalistiese wyse, ' $n$ mens in die duister laat oor die aanvaarbaarheid of waarheid van die resultate daarvan. Dit is volgens Stoker nie bewysbaar of weerlegbaar nie, omdat dit selfevident sou wees. Wat gebeur as dieselfde metode verskillende en weersprekende resultate sou oplewer? Word daar weer op die ou ooreenstemming tussen die denke en die saak waaroor nagedink word, teruggeval? Ook dít kan nie as finale kriterium vir die waarheid diens doen nie, aangesien almal ook nie die resultate daarvan sal aanvaar nie.

Hierdie vrae hang vervolgens saam met die feit dat Stoker (vgl. hierbo) nie duidelik sy diafanerotiese metode van die fenomenologiese onderskei nie. Hy sê byvoorbeeld nie presies watter elemente hy van Husserl en Scheler se fenomenologie oorgeneem het en wat presies die vooronderstellings daaraan verbonde was wat hy verwerp het nie. Dit maak dit moeilik om die positiewe of negatiewe invloed van die fenomenologie op sy denke te bepaal.

Van der Walt (2009) is dus verplig om slegs die volgende konklusie te maak:

It can only be stated here that Stoker's diafanerotic method cannot simply be equated with the phenomenological method. Nor can it be taken in good faith that Stoker didn't incorporate some aspects of phenomenology that is irreconcilable with a Scriptural philosophy. (bl. 73-74)

Ten slotte het ek ook probleme met die sogenaamde 'wese' van die dinge wat die fenomenologiese metode sou ontbloot. Ek vermoed dat die eeue oue logosspekulasie (bv. by Bavinck) hier kop uitsteek. By Scheler was dit waarskynlik'n oorblyfsel van sy vroeëre Thomistiese agtergrond.

\section{Gevolgtrekking ten opsigte van die moontlike invloede op Stoker se denke}

Terugskouend op die voorafgaande sou breedweg gestel kon word dat veral twee denkstomings in die filosofie van Stoker ineengevloei het. Die een is Bavinck se sterk skolastiesgekleurde gereformeerde teologie en die ander is Scheler se irrasionalisties-fenomenologiese filosofie. Dit mag dus wees dat Stoker, byvoorbeeld ten opsigte van die openbaringsidee, Scheler deur die oë van Bavinck gelees het of Bavinck deur die bril van Scheler.

Hoewel hierdie twee invloedlyne nie oral in Stoker se denke van mekaar geskei kan word nie, sou 'n mens tog kon sê dat Bavinck se invloed veral duidelik is by Stoker se ontologie, antropologie en wetenskapsleer, terwyl die invloed van Scheler sterk in Stoker se kenteorie en metodologie na vore tree.
Ten spyte van die voorafgaande mag egter nie vergeet word dat Stoker wel 'n leerling van veral Bavinck en Scheler was, maar geen onoorspronklike naprater nie. Hy het steeds krities met hulle denkgoedere omgegaan.

\section{Stoker se besondere bydrae tot 'n Christelike filosofie}

Sonder om op volledigheid aanspraak te maak, word hier alleen baie kortliks (soos ook in die vorige artikel oor Vollenhoven) slegs enkele uitstaande bydraes van Stoker aangestip wat myself ook getref het.

- In die algemeen het Stoker 'n onskatbare waardevolle rol gespeel om aan die ideaal van 'n Christelike beoefening van die wetenskap aan die destydse $\mathrm{PU}$ vir $\mathrm{CHO}$ gestalte te gee. Hierdie ideaal het hy nooit prysgegee nie (vgl. Stoker 1976).

- Stoker was egter nie 'n ivoortoring-filosoof nie. Hy was nou betrokke by sy land en sy mense en het met talle populêre publikasies ook leiding aan hulle denke probeer gee.

- Wat sy filosofie van die skeppingsidee betref, moet gesê word dat dit die oorspronklike produk van 'n selfstandige denker is. Hy kan met reg as een van die drie vaders van 'n reformatoriese filosofie beskou word en verdien daarom meer aandag as wat hy tot dusver ontvang het. 'n Voorbeeld van sy oorspronklikheid is sy skep van nuwe terme soos idion en teaal.

- Nog 'n voorbeeld is die twee nuwe dimensies van die werklikheid deur hom onderskei, naamlik 'n dimensie van waardes en van gebeurtenisse.

- Heel moontlik is Stoker se belangrikste bydrae sy diepgaande besinning oor metodes in die wetenskap (vgl. Stoker 1969). Hy het daarmee 'n terrein betree wat nie deur sy destydse medestanders sistematies en volledig ontgin is nie. Gelukkig is hierdie bydrae intussen verder uitgebou deur Venter (1981:501 e.v.) en ook Van der Walt (2009). Van der Walt (2009:65-66, 91-92) gee 'n samevatting van die spesifieke bydraes van Stoker op die gebied van die metodologie - 'n intellektuele rykdom wat nog deur baie ontdek moet word.

Soos reeds vroeër aangedui (onder 'Opset' hierbo) kan nou oorgegaan word tot die onderlinge debat tussen die grondleggers van 'n reformatoriese filosofie gedurende die vorige eeu.

\section{Onderlinge verryking en debat}

Soos reeds (onder 'Stoker self lig die sluier') genoem, erken Stoker (1970:334) dat hy van Vollenhoven en Dooyeweerd talryke en fundamentele nuwe insigte kon oorneem. In Stoker (1935:18) gee hy selfs die eer aan hierdie twee ander lede van die driemanskap dat hulle die eerstes was wat aan hom getoon het dat 'n Calvinistiese filosofie (nie net 'n teologie nie) moontlik is. ('n Mens moet Stoker se eerlikheid en beskeidenheid waardeer. Dooyeweerd was geneig om Stoker en selfs Vollenhoven - by wie hy filosofies baie geleer het - slegs as 'medewerkers' te beskou.) 
Nadat Stoker oortuig is van die moontlikheid van 'n Christelike filosofie, het hy dit egter op eie wyse uitgewerk. Dit blyk duidelik uit die onderlinge debat tussen die driemanskap en hulle navolgers.

\section{Beperkings}

Hierdie artikel bou voort op wat reeds in die vorige artikel oor Vollenhoven (vgl. Van der Walt 2013) geskryf is oor sogenaamde binnegevegte in die reformatoriese filosofie. Daarin is reeds genoem hoe navolgers van Vollenhoven, Stoker en Dooyeweerd kritiek op die twee ander vaders (in wie se gedagtelyn hulle nie gewerk het nie) gelewer het.

Ons beperk ons hier tot kritiek vanuit geesgenootlike hoek gelewer. Persone wat buite die tradisie staan, het ook van hulle laat hoor (vgl. 'Wanvoorstellings van sekere binneen buitestanders oor 'n reformatoriese filosofie' hieronder.) Verder beperk ons ons tot die debat tussen Stoker en Dooyeweerd en laat Vollenhoven eers uit.

'n Derde beperking behels die volgende: Aangesien dit onmoontlik is om binne die beperkte ruimte van hierdie artikel in te gaan op alles wat die debatte inhoudelik behels het, moet hier volstaan word deur slegs te vermeld deur wie die debatte gevoer is met die noodsaaklikste bibliografiese verwysings, sodat die onderlinge verskille deur geïnteresseerde lesers opgevolg kan word.

\section{Kritiek op Stoker se filosofie vanuit 'n Dooyeweerdiaanse hoek}

Kritiek op Stoker se denke is onder andere gelewer deur Dooyeweerd self en twee van sy Suid-Afrikaanse navolgers.

\section{Dooyeweerd se vrae aan Stoker}

Navorsers wat maklik op die spoor van Dooyeweerd se evaluering van Stoker se filosofie wil kom, kan Dooyeweerd (1958:231) raadpleeg (vgl. veral Dooyeweerd 1957:64-76). Ek noem net die punte waarop Dooyeweerd van Stoker verskil hier op: Eerstens, Dooyeweerd verwerp Stoker se idee van substansie (wat Stoker later met idiostansie of eiestandigheid vervang); tweedens kritiseer hy Stoker se tydsbeskouing; derdens, Stoker se digotomistiese antropologie en idees oor die beeld van God in die mens; vierdens, die feit dat Stoker 'n onmiddellike (teale) verhouding tussen die kosmos en God aanvaar (in plaas van via die mens as sentrum van die skepping); vyfdens verwyt hy Stoker ook van neo-skolastieke trekke en laastens van sterk irrasionalistiese beïnvloeding deur Scheler.

\section{Kock en Malan se kritiek}

Onder leiding van E.A. Venter het 'n sterk vesting van Dooyeweerd se filosofie aan die Universiteit van die (Oranje) Vrystaat ontstaan wat tot ' $n$ intense gesprek met Stoker in Potchefstroom gelei het. Twee voorbeelde hiervan is Kock (1972) en Malan (1968).

Kock bespreek verskillende standpunte oor 'n Christelike filosofie (ook persone buite die tradisie se kritiek daarop). Hy doen dit egter deurgaans as 'n oortuigde voorstander van
Dooyeweerd se denke. Sy gesprek en verskille met Stoker kom op verskillende plekke na vore en is die moeite werd om na te lees (vgl. Kock 1972:14 e.v., 43 e.v., 157 e.v., 191 e.v.)

Malan (1968) het onder S.U. Zuidema aan die Vrije Universiteit gepromoveer. Sy kritiek op Stoker het destyds heelwat opslae gemaak, sodat Stoker dit noodsaaklik geag het om homself te verdedig (vgl. Stoker 1970:411-433).

\section{Kritiek van Stoker op Dooyeweerd se filosofie}

Stoker se kritiese gesprek met Dooyeweerd begin reeds in Stoker (1933a), maar word ook in sy latere werke voortgesit. Daar bestaan veel meer verskille met Dooyeweerd as wat Schulze (1994:473 e.v.) noem, naamlik sy wetsidee; sy beskouing oor die verhouding tussen teologie en filosofie, en idealisties-humanistiese (Kantiaanse en neo-Kantiaanse) reste by Dooyeweerd. Hierby sou Stoker se breedvoerige en belangrike kritiek op Dooyeweerd se transendentale metode (vgl. Van der Walt 2009:51-65) gevoeg kon word. Verder bevraagteken Stoker Dooyeweerd se idee dat die menslike hart botydelik sou wees; asook sy klem op slegs 'n religieuse (i.p.v. teale) verhouding tot God; die antroposentrisme van sy kosmologie en sy veronderstelde intrakosmiese konsentrasiepunt; sy oorbeklemtoning van die menslike natuur van Christus (i.p.v. 'n meer trinitariese, teosentriese perspektief); sy sterk klem op logiese denke; en laastens Dooyeweerd se beperking van die Bybelse boodskap tot slegs skepping, sondeval en verlossing.

\section{Wedersydse kritiek is noodsaaklik}

Vir hedendaagse lesers mag soveel onderlinge verskille verwarrend en ontmoedigend wees. Stoker het egter sowel die verskille tussen homself, Bavinck, Vollenhoven en Dooyeweerd (vgl. Stoker 1970:218 e.v.) as die ooreenkomste tussen hulle almal (vgl. Stoker 1970:225) erken. Ek het 'n vermoede dat huidige lesers veral in laasgenoemde geïnteresseerd sal wees. Vir 'n lewende tradisie is kritiek egter onontbeerlik.

Met hierdie bydrae het die skrywer egter ook nog 'n laaste doel voor oё. Dit bring ons tot die slotafdeling van hierdie artikel:

\section{Wanvoorstellings van sekere binne- en buitestanders oor 'n reformatoriese filosofie}

Ek noem eers enkele kritiekpunte wat dikwels teen 'n Christelik-reformatoriese benadering in die filosofie na vore gebring word, om vervolgens breedvoeriger daarop te antwoord.

\section{Kritiek}

Hier volg 'n lysie van wat 'n mens soms hoor en lees:

- As gevolg van jarelange 'inteling' sou reformatoriese filosowe mekaar gewoon napraat - daar bestaan by hulle geen plek vir onderlinge verskille en kritiek nie. 
- Hierdie feit sou weer lei tot 'n soort 'dogmatisme' of sisteemdwang - almal 'sing' presies dieselfde ou wysgerige deuntjie.

- Die reformatoriese tradisie is dus 'in sement gegiet'. Dit het dus staties gebly vir die afgelope 75 jaar met weinige veranderings of vernuwings.

- As gevolg van 'n antitetiese houding het dit in isolasie ontstaan en ontwikkel, sodat dit niks geleer het of wil leer van andersdenkendes nie.

- Reformatoriese filosofie is dus niks anders as 'n gekamoefleerde teologie nie.

Indien bogenoemde menings waar is, het die huidige postmodernisme sulke kritici die nodige addisionele skietgoed gegee om vandag nog meer afsydig teenoor hierdie tradisie te staan. Die reformatoriese filosofie (as 'n sisteem) kan daarvolgens as een van die 'groot verhale' beskou word, wat slegs versmorend en onderdrukkend sou werk.

Natuurlik ontbreek die nodige selfkritiek dikwels by postmoderniste wat hulle sou laat besef dat hulle eie denkskool nie in mindere mate ' $n$ groot verhaal - met diskriminerende gevolge vir alle nie-postmoderniste - geword het nie. (Vir 'n grondige kritiek op die postmodernisme, vgl. byvoorbeeld Kok 1998:164-173; Middleton \& Walsh 1995.)

\section{'n Antwoord}

Dit is jammer dat ' $n$ mens bogenoemde soort kritiek selfs onder gereformeerde geesgenote of binnestanders vind. Omdat daar agter bogenoemde negatiewe opinies meestal ' $n$ ander lewensvisie en filosofie skuil, is dit moeilik - byna onmoontlik - om dit te weerlê. Tog word die volgende genoem omdat oningeligtheid ook hier 'n rol kan speel.

\section{Geen napraters nie}

Die gedagte dat reformatoriese denkers almal napraters of 'his master's voice' van Vollenhoven, Stoker of Dooyeweerd sou wees, is onwaar. Dit blyk reeds uit die onderlinge kritiek wat hierdie drie grondleggers van die reformatoriese tradisie op mekaar gehad het, afgesien nog van die kritiek van hulle navolgers.

\section{Geen geslote sisteem nie}

Dieselfde feit weerlê ook die aanklag dat dit 'n geslote, statiese sisteem sou wees. (In ons moderne, dinamiese tyd sou so 'n verstarde sisteem heelwaarskynlik nie 75 jaar kon oorleef nie!) Dooyeweerd het egter reeds in 1956 so 'n aanklag ten sterkste ontken toe hy oor die Reformatoriese filosofie die volgende geskryf het:

$\mathrm{Zij}$ is ook geen afgesloten 'stelsel', zij meent niet binnen het vlak der wijsgerige bezinning het waarheidsmonopolie te bezitten... het stempel ter onaantasbaarheid zou ontvangen. Zij eist als wijsbegeerte in 't geheel geen gepriviligeerde positie op, maar wil integendeel een reële basis scheppen voor het wijsgerig gesprek tussen de verschillende strominge, die zich vaak tegenover elkaar afsluiten in een geestelijk isolement, dat slechts tot zelfoverschatting en verstarring kan leiden. (Aangehaal in Van Dijk \& Stellingwerff 1961:67)

\section{Geen isolasie nie}

Dit is ook nie waar dat reformatoriese filosowe niks van buitestanders wou leer nie. Reformatoriese denkers dink wel duidelik antisinteties, omdat hulle 'n werklike bybelsgeoriënteerde, Christelike filosofie voorstaan, maar beslis nie antiteties nie. Soos duidelik uit die voorafgaande bladsye oor byvoorbeeld Stoker blyk, kon hulle, omdat almal van hulle ook kinders van hulle eie tyd was, egter nie volledig daarin slaag om hulle van vreemde, selfs nie-bybelse invloede te bevry nie.

Hierby kan nog gevoeg word dat Stoker in Nederland en die VSA, Vollenhoven in Kanada en Suid-Afrika en Dooyeweerd as gasdosent dwarsoor die wêreld opgetree het, byvoorbeeld aan verskillende instellings in Nederland, België, Frankryk, Kanada, die VSA en Suid-Afrika (vgl. Van Dijk \& Stellingwerff 1961:69). Hierdie buitelandse optredes is onder andere gemotiveer deurdat, naas die handhawing van 'n eie visie, ook noue kontak met andersdenkendes noodsaaklik was, omdat die driemanskap geen starheid van denke of isolasie wou hê nie.

Die omgekeerde is ook waar, naamlik dat filosowe uit ander denkrigtings bereid was om van die reformatoriese filosofie iets te leer. Dit blyk byvoorbeeld uit die belangstelling van Rooms-Katolieke denkers in Dooyeweerd se denke (vgl. byvoorbeeld Robbers 1949; Marlet 1954 en die bydraes van Louet Feisser en Marlet in Van Dijk \& Stellingwerff 1961:18-35, 36-41). Ongeveer 'n dosyn proefskrifte is alreeds oor Dooyeweerd deur geesgenote, sowel as andersdenkendes geskryf (vgl. Henderson 1994:13-14, voetnota).

\section{Skoolvorming nie verkeerd nie}

Hierby moet nog gevoeg word dat (ook Christelik-filosofiese) skoolvorming nie noodwendig 'n doodsonde is nie, maar juis 'n krag of sterk punt kan wees. Filosofie kan nie effektief op individualistiese wyse beoefen word nie, maar vereis 'n denkgemeenskap. So 'n 'skool' bied ook die geleentheid vir sy verskillende deelnemers om, elk op sy of haar eie gebied gedetailleerde bydraes te kan lewer.

\section{Christelike filosofie is nie ' $n$ bedreiging nie}

Dit is belangrik om hier te beklemtoon dat die standpunt van sekere (selfs gereformeerde) teoloë dat enige filosofie - ook 'n Christelike filosofie - 'n bedreiging vir die teologie inhou, nie wetenskaplik verantwoord is nie. (Natuurlik is onbybelse filosofieë lewensgevaarlik - idees het voete!) Tereg word in die bundel onder redaksie van Van den Brink, Geertsema en Hoogland (1997) daarvoor gepleit dat, veral in ons steeds groeiende sekulêre tyd, Christelike teoloë en filosowe hande behoort te vat en nouer saam te werk. Insgelyks bepleit Du Plessis (2011) vir 'n gesamentlike werkgroep van teoloë, filosowe en ander wetenskaplikes.

Die teologie kan byvoorbeeld met noukeurige Skrifeksegese 'n groot diens aan die filosofie bewys. Omgekeerd kan die filosofie (vgl. Vollenhoven 2011:201-214) onder andere die volgende twee dienste aan die teologie lewer: Eerstens, die 
teologie daarvan bewus maak dat dit nie in isolasie van 'n Christelike filosofie kan werk nie, aangesien dit (die teologie) - ook al is dit nie daarvan bewus nie - van dieperliggende lewensbeskoulike en wysgerige veronderstelling uitgaan. Tweedens, 'n Christelike filosofie kan teoloë ook attent maak op die gevare van sintesedenke, met ander woorde pogings om, al is dit onbewustelik, onbybelse filosofieë in die Skrif in te lees en so te sanksioneer.

\section{Nie 'n gekamoefleerde teologie nie}

Die reformatoriese filosofie is ook geen gekamoefleerde teologie nie. Die agtergrond van so 'n gedagte is die eeue oue idee dat alleen die teologie 'n Christelike inhoud sou hê, terwyl die wysbegeerte van nature iets neutraal sou wees. (Christelike wysgere is volgens hierdie visie dalk nog moontlik, maar nie 'n Christelike wysbegeerte nie.) Bybels georiënteerde idees, wat deur nie-teoloë in ander vakgebiede gebruik word, sou dan as 'teologie' beskou word. Voorbeelde hiervan is ' $n$ teologiese ekonomie, teologiese ekologie en so meer.

Die denkers in hierdie tradisie het hulle egter met egte filosofiese probleme besig gehou en ook daarvoor erkenning gekry. Vier Stalspryse vir Filosofie van die Suid-Afrikaanse Akademie vir Wetenskap en Kuns is reeds aan vier reformatoriese denkers - waarvan Stoker die eerste was - in Suid-Afrika toegeken.

\section{Nie beperk tot Suid-Afrika of Nederland nie}

Ten slotte word nog vermeld dat die reformatoriese denke nie net tot twee stede of lande (Amsterdam en Potchefstroom, Nederland en Suid-Afrika) beperk is nie, maar alreeds 'n internasionale statuur verkry het (vgl. Van der Walt 2010d, 2010e; Glas 2011a:14, 16, 2011b:48-49). By die onlangse Internasionale Simposium van die Vereniging vir Christelike Filosofie in Amsterdam op 15-19 Augustus 2011, was daar nie minder nie as 250 deelnemers uit ongeveer 30 verskillende lande teenwoordig.

\section{Ten slotte}

Om, soos Stoker, Christelik-reformatories te dink en werklike Christelike wetenskap te beoefen, is nie ' $n$ eenvoudige en maklike roeping nie. Daarom moet ons hom erkenning gee vir wat hy bereik het. Hart (1976) sluit tereg sy opstel oor die ideaal van Christelike wetenskap soos volg op 'n beskeie manier af:

The idea of Christian scholarship to me is filled with intrigue and challenge, with hardship and trouble, with joy and reward, with sin and misery, with salvation and redemption and above all with needs. There are those who sneer at the idea and there are others who believe with some romantic nostalgia that the idea has had its time... Maybe it should teach us that the suction of modern (secular) scholarship away from redemption is greater than we had thought it to be. In that case let us have the humility to see the need for implementing the idea of Christian scholarship. (bl. 92-93)

Soos aan die begin van hierdie artikel gestel is, was die oogmerk daarvan om in hierdie nood te voorsien. Dit is gedoen deur die verhaal rondom Stoker en sy filosofie, wat slegs 'n deeltjie van die breër reformatoriese tradisie is, op eenvoudige wyse aan die jonger generasie oor te dra. Daarin is gepoog om Stoker nóg as 'n vae legende, nóg as 'n heilige ikoon voor te stel, maar dat hy, selfs na sy dood, as 'mentor' vir'n nuwe geslag kan optree.

Die bekende teoloog, Bonhoeffer, wat deur die nazi-Duitsers tydens die Tweede Wêreldoorlog vermoor is, skryf kort voor sy dood nog die volgende (Bonhoeffer 1968): 'Die laaste vraag is nie hoe ek die toneel verlaat nie, maar hoe die volgende generasie verder sal leef.' Dit was ook die grootste motivering vir hierdie bydrae, naamlik om op die smeulende kole van ' $n$ belangrike tradisie te blaas, sodat dit weer opvlam en die vlammetjie van reformatoriese entoesiasme deur die jonger geslag verder gedra kan word.

\section{Erkenning Mededingende belange}

Die outeur verklaar dat hy geen finansiële of persoonlike verbintenis het met enige party wat hom nadelig kon beïnvloed in die skryf van hierdie artikel nie.

\section{Literatuurverwysings}

Bakker, R., 1966, Die geschiedenis van het fenomenologisch denken, Aula, Utrecht. Bavinck, H., 1906, Gereformeerde Dogmatiek, Kok, Kampen.

Bavinck, H., 1908, Wijsbegeerte der openbaring, Kok, Kampen.

Beijk, A.A. \& Van der Merwe, N.T., 1994, 'H.G. Stoker as student - die wysgerige denkklimaat en akademiese wisselwerking met Scheler en Buytendijk', Koers 59(3\&4), 501-528.

Bingle, H.J.J. \& Du Plessis, P.G.W. (eds.), 1971, Truth and reality; philosophical perspectives on reality dedicated to prof. H.G. Stoker, De Jong's Bookshop, Braamfontein. PMid:5001990, PMCid:1799970

Bochenski, I.M., 1954, Zeitgenössishen Denkmethoden, Francke Verlag, Bern/München. PMid:13188039

BOGP, 1953, Agter tralies en doringdraad, Pro Ecclesia, Stellenbosch.

Bonhoeffer, D., 1968, Verzet en overgave, W. Ten Have, Amsterdam.

Bremmer, R.H., 1961, Herman Bavinck als dogmaticus, Kok, Kampen.

Buytendijk, F.J.J., 1951, De vrouw; haar natuur, verschijning en bestaan - een existentieelpsychologische studie, Spectrum, Utrecht.

De Boer, Th., 1968, De ontwikkelingsgang in het denken van Husserl, Van Gorcum, Assen.

De Boer, Th., 1977, 'Edmund Husserl', in C.P. Bertels \& E. Petersma (reds.), Filosofen van de 20e eeuw, bl. 87-100, Van Gorcum, Assen/Amsterdam.

De Klerk, P., 1991, 'Die ideologie van die Ossewa Brandwag', in P.F. van der Schyff (red.), Die Ossewa Brandwag: 'n vuurtjie in droë gras, bl. 292-331, Dept. Geskiedenis, PU vir CHO.

Dooyeweerd, H., 1957, A new critique of theoretical thought, vol. 3, Presbyterian and Reformed Pub. Co., Philadelphia \& H.J. Paris, Amsterdam.

Dooyeweerd, H., 1958, A new critique of theoretical thought, vol. 4, The Presbyterian and Reformed Pub. Co., Philadelphia \& H.J. Paris, Amsterdam.

Du Plessis, P.G.W., 2011, "n Werksgroep vir teologie, filosofie en ander vakdissiplines', In die Skriflig/In Luce Verbi 45(2\&3), 307-328.

Duvenage, B., 1993, 'In memoriam prof. H.G. Stoker: 'n Palmboom en 'n seder', Die Kerkblad Oktober, 21-22.

Fernhout, H., 1975, 'Man, faith and religion in Bavinck, Kuyper and Dooyeweerd', MA thesis, Dept. of Philosophy, Institute for Christian Studies, Toronto.

Glas, G., 2011a, 'What is Christian Philosophy?' Pro Rege 49(1), 1-17.

Glas, G., 2011b, Twijfel, bewys, overgave; over christelijke filosofie, Sjibolet, Amsterdam. Hart, H., 1976, 'The idea of Christian scholarship', in H.J.J. Bingle e.a., Christian higher education; the contemporary challenge, pp. 69-97, Institute for the Advancement of Calvinism, Potchefstroom. PMid:1260853

Heideman, E.P., 1959, The relation between revelation and reason in E. Brunner \& $\mathrm{H}$. Bavinck, Van Gorcum, Assen.

Henderson, R.D., 1994, 'Illuminating law; the construction of Herman Dooyeweerd's philosophy, 1918-1928', Dissertation, Free University, Amsterdam.

Heyns, J.A., 1994, 'Die betekenis van H.G. Stoker se filosofie vir die teologie', Koers 59(3\&4), 455-472.

Husserl, E., 1964, The idea of phenomenology, M. Nijhoff, The Hague. 
Klapwijk, J., 1980, 'Honderd jaar filosofie aan de Vrije Universiteit', in M. Van Os, \& W.J. Wieringa (reds.), Wetenschap en rekenschap 1880-1980; een eeuw van wetenschapsbeoefening en wetenschapsbeschouwing aan de Vrije Universiteit, wetenschapsbeoefening en
pp. 529-593, Kok, Kampen.

Kock, P. de B., 1972, Christelike Wysbegeerte - standpunte en probleme, SACUM Bpk, Bloemfontein.

Kok, J.H., 1998, Patterns of the Western mind; a Reformed Christian perspective, Dordt College, Sioux Center, lowa.

Kruger, J.A., 1975, 'Scripturally directed action: A radical stance in contemporary society biographical notes on prof. J.A.L. Taljaard', Koers 40(4, 5 \& 6), 229-235.

Lauer, Q., 1965, Phenomenology; its genesis and prospect, Harper Torchbooks, New York.

Malan, D.J., 1968, 'n Kritiese studie van die wysbegeerte van H.G. Stoker vanuit die standpunt van H. Dooyeweerd, Buijten \& Schipperheijn, Amsterdam. PMCid:1187029

Marlet, M.Fr.J., 1954, Grundlinien der kalvinistischen Philosophie der Gesetzidee als christliche Transcendentalphilosophie, Karl Zink, München.

Middleton, J.R. \& Walsh, B.J., 1995, Truth is stranger than it used to be; biblical faith in a postmodern age, InterVarsity Press, Downers Grove, Illinois.

Raath, A.G.W. 1994a, 'Soli Deo gloria: die lewe en werk van prof. dr. H.G. Stoker (4 April 1899-15 Mei 1993)', Koers 59(3\&4), 343-362.

Raath, A.G.W., 1994b, 'Die akademiese nalatenskap van prof. H.G. Stoker', Koers 59(3\&4), 377-398.

Robbers, H., 1949, 'Het Calvinistische Wijsbegeerte der Wetsidee in gesprek met het Thomisme', Studia Catholica 24, 161-171.

Scheler, M., 1955, Vom Umsturz der Werte, Francke Verlag, Bern.

Schulze, L.F., 1994, 'Aspekte van Stoker se kritiek op die Wysbegeerte van die Wetsidee', Koers, 59(3\&4), 473-390.

Schutte, G.J., 2005, De Vrije Universiteit en Zuid-Afrika, 1880-2005, (2 dele), Meinema, Zoetemeer.

Smith, N., 2009, Die Afrikaner Broederbond, LAPA Uitgewers, Pretoria.

Spiegelberg, H., 1969, The phenomenological movement: A historical introduction, M. Nijhoff, The Hague.

Spier, J.M., 1959, Van Thales tot Sartre; wijsgeren van oude en nieuwe tijd, Kok, Kampen.

Stellingwerff, J., 1992, D.H.Th. Vollenhoven (1892-1978); reformator der wijsbegeerte, Ten Have, Baarn.

Stellingwerff, J., 2006, Geschiedenis van de Reformatorische Wijsbegeerte, Stichting voor Reformatorische Wijsbegeerte, Zoest.

Stoker, H.G. (Jnr), 1983, 'Die vraagstuk van die deontologie in die filosofie van H.G. Stoker', MA verhandeling, PU vir CHO.

Stoker, H.G., 1925, Das Gewissen; Erscheinungsformen und Theorien, Friedrich Cohen, Bonn.

Stoker, H.G., 1933a, Die nuwe wysbegeerte aan die Vrije Universiteit, De Bussy, Pretoria. Stoker, H.G., 1933b, Die slakkehuisteorieë van die bewussyn, De Bussy, Pretoria.

Stoker, H.G., 1935, 'The possibility of a Calvinistic philosophy', The Evangelical Quarterly 7, 17-23.

Stoker, H.G., 1941a, Die stryd om die ordes, Calvyn Jubileum Boekefonds, Potchefstroom. Stoker, H.G., 1941b, 'Grepe uit 'n Calvinistiese Wysbegeerte: Phanerosis en wysbegeerte', Koers 8(2), 140-149.

Stoker, H.G., 1953, 'Enkele sosiologiese, psigologiese en etiese opmerkings oor die Koffiefonteinse Boerekamp', in BOGP, Agter tralies en doringdraad, bl. 306-325, Pro Ecclesia, Stellenbosch.

Stoker, H.G., 1967a, 'At the crossroads: apartheid and university freedom in South Africa', in H.G. Stoker, Oorsprong en rigting, deel 1, pp. 209-222, Tafelberg, Kaapstad.

Stoker, H.G., 1967b, 'A phenomenological analysis of conscience', in H.G. Stoker, Oorsprong en rigting, deel 1, pp. 305-322, Tafelberg, Kaapstad.

Stoker, H.G., 1967c, 'Calvin and ethics', in H.G. Stoker, Oorsprong en rigting, deel 1, pp. 284-304, Tafelberg, Kaapstad.

Stoker, H.G., 1967d, Oorsprong en rigting, deel 1, Tafelberg, Kaapstad.

Stoker, H.G., 1969, Beginsels en metodes in die wetensklap, Boekhandel de Jong, Johannesburg.

Stoker, H.G., 1970, Oorsprong en rigting, deel 2, Tafelberg, Kaapstad.

Stoker, H.G., 1971, 'Reonnoitering the theory of knowledge of prof.dr. Cornelius van Til', in E.R. Geehan (ed.), Jerusalem and Athens; critical discussions on the theology and apologetics of Cornelius van Til, pp. 25-70, Presbyterian and Reformed Pub. Co., Nutley, New Jersey.

Stoker, H.G., 1976, 'Our Christian calling of doing science', in H.J.J. Bingle et al., Christian higher education - the contemporary challenge, pp. 134-158, Institute for the Advancement of Calvinism, Potchefstroom.

Stoker, H.G., 2007, Uit, deur en tot God is alle dinge: Werke van prof. H.G. Stoker, 1970, CD-ROM, VCHO, Bloemfontein.

Stoker, H.G., 2008, 'A collection of the academic publications of South African Reformational philosopher, H.G. Stoker', viewed $18 \mathrm{Apr} 2012$, from http://www. stevebishop.blogspot.com/2008-07-01 archive.htm
Stoker, H.G., 2010, Philosophy of the Creation Idea, transl. J.L. van der Walt, Oorsprong en rigting, vol. 2, pp. 202-230, School of Philosophy, North-West University, Potchefstroom.

Van den Brink, G., Geertsema, H.G. \& Hoogland, J., 1997, Filosofie en teologie; een gesprek tussen Christen-filosofen en theologen, Buijten \& Schipperheijn, Amsterdam.

Van der Hoeven, J., 1963, Kritische ondervraging van de fenomenologische rede, Buijten \& Schipperheijn, Amsterdam.

Van der Hoeven, J., 1965, The rise and development of the phenomenological movement, The Association for Reformed Scientific Studies, Hamilton, Ontario. PMCid:1928798

Van der Merwe, N.T., 1993, 'In memoriam H.G. Stoker (04/04/1899-16/05/1993)', Philosophia Reformata 58, 95-97.

Van der Merwe, N.T., 1994, 'H.G. Stoker as mentor', Koers 59(3\&4), 363-376.

Van der Schyff, P.F., 2003, Wonderdaad! Die Puk tot 1951: Wording, vestiging en selfstandigheid, $\mathrm{PU}$ vir $\mathrm{CHO}$.

Van der Schyff, P.F., 2005, 'H.G. (Henk) Stoker: Ondersoekende gees', in P.F. van der Schyff, Sages en legendes en ander stories oor die Puk, bl. 125-128, NoordwesUniversiteit, Potchefstroom.

Van der Walt, B.J. (red.), 1980, Die inslag van die Calvinisme in Suid-Afrika; ' bibliografie van Suid-Afrikaanse tydskrifartikels, Instituut vir die Bevordering van die Calvinisme, Potchefstroom.

Van der Walt, B.J., 1993, 'H.G. Stoker - 'n kosbare nalatenskap', Woord en Daad 33(344), 5-6.

Van der Walt, B.J., 1995, Die hand in eie boesem; op soek na Afrikaner-identiteit, (Brosjure no. 61), Instituut vir Reformatoriese Studie, Potchefstroom. PMCid:502281

Van der Walt, B.J., 2010a, 'Imaging God in the contemporary world', in B.J. van der Walt, At home in God's World, pp. 325-366, Institute for Contemporary der Walt, At home in God's World,
Christianity in Africa, Potchefstroom.

Van der Walt, B.J., 2010b, 'Besit waardes enige rigtinggewende waarde?', Koers 75(2), 293-324.

Van der Walt, B.J., 2010c, 'Die waarde van waardes', Koers 75(4), 709-750. http:// dx.doi.org/10.4102/koers.v75i4.104

Van der Walt, B.J., 2010d, 'An overview of the global presence of a Christian Reformational philosophy and scholarship', in B.J. van der Walt, At home in God's world, pp. 127-151, Instititute for Contemporary Christianity in Africa, Potchefstroom.

Van der Walt, B.J., 2010e, 'Wêreldwye belangstelling in Christelike wetenskapsbeoefening en Christelike hoër onderwys', Tydskrif vir Christelike Wetenskap 46, 111-132.

Van der Walt, B.J., 2013, 'Die Christelike filosofie van D.H.Th. Vollenhoven (1892-1978): Hoe dit ontstaan en verder ontwikkel het', In die Skriflig/In Luce Verbi 47(1), ter perse.

Van der Walt, M.F., 2009, 'The value of Stoker's methodology for Reformational philosophy', Unpublished thesis, North-West University, Potchefstroom.

Van der Walt, S.P., 1953, Die wysbegeerte van dr. Herman Bavinck, Pro Rege-Pers, Potchefstroom.

Van Dijk, W.K. \& Stellingwerff, J. (reds.), 1961, Perspectief; feestbundel van de jongeren bij het vijfentwintig jarig bestaan van de Vereniging voor Calvinistische Wijsbegeerte, Kok, Kampen.

Van Eeden, E.S., 2006, "n Historiese perspektief op die realisering van die 'CHO' van die Puk as 'n stem uit Potchefstroom tot 2003', Tydskrif vir Christelike Wetenskap 42(4), 113-137.

Van Peursen, C.A., 1967, Fenomenologie en werkelijkheid, Aula, Utrecht.

Van Peursen, C.A., 1968, Fenomenologie en analitische filosofie, W. de Haan, Hilversum \& J.M. Meulehoff, Amsterdam. PMid:5685646

Van Wyk, J.H., 2001, 'Liberale konserwatisme? H.G. Stoker en die ideologie van apartheid - 'n verkenning', in J.H. van Wyk, Etiek en eksistensie, pp. 188-213, Potchefstroom Teologiese Publikasies, Potchefstroom.

Vander Stelt, J.C., 2012, Herman Bavinck (1854-1921), Chapter 4, (unpublished manuscript).

Veenhof, J., 1968, Revelatie en inspiratie; de openbarings- en Schriftbeschouwing van Herman Bavinck in vergelijking met die der ethische theologie, Buijten \& Schipperheijn, Amsterdam.

Venter, J.J., 1981, 'Geloofsgebonde denke by Anselmus; 'n studie van sy wysgerige metode', DPhil proefskrif, PU vir CHO.

Verburgh, M.E., 1989, Herman Dooyeweerd; leven en werk van een Nederlands Christen-wijsgeer, Ten Have, Baarn. PMid:2707358

Vollenhoven, D.H.Th. \& Bril, K.A. (red.), 1982, Vollenhoven's laatste werk, VU Boekhandel/ Uitgeverij, Amsterdam.

Vollenhoven, D.H.Th., Bril, K.A. \& Boonstra, P.J. (reds.), 2000, Schematische Kaarten filosofische concepties in probleemhistorisch verband, De Zaak Haes, Amstelveen.

Vollenhoven, D.H.Th., 2011, 'Wijsbegeerte en theologie', in K.A. Bril \& R.A. Nijhoff (reds.), Vollenhoven, D.H.Th., Gastcolleges Wijsbegeerte; erfenis voor het heden, bl. 201-214, De Zaak Haes, Amstelveen.

Zylstra, A.B., 1975, 'Introduction', in L. Kalsbeek, Contours of a Christian philosophy: An introduction to Herman Dooyeweerd's thought, pp. 14-33, Wedge Pub. Foundation, Toronto. 